\title{
MAJAS SARKASME DALAM PENULISAN KOMENTAR PADA "WARTAWAN SENIOR BONGKAR KEBUSUKAN ANTASARI, NASRUDIN DAN PERMAINAN JAHAT PDIP”
}

\author{
(Sarcasm Metaphor in The Writing of Comments in "Wartawan Senior Bongkar \\ Kebusukan Antasari, Nasrudin dan Permainan Jahat PDIP (Senior Journalist \\ Reveals Aantasari's Evil, Nasrudin and PDIP's Engage in Some Evils")
}

\author{
Marnetti \\ Kementerian Pendidikan dan Kebudayaan \\ Balai Bahasa Provinsi Riau, Panam, Pekanbaru 28293 \\ Pos-el: marnettinurel@yahoo.com
}

\begin{abstract}
Abstrak: Edy A Effendi adalah wartawan senior yang menulis komentar tentang Antasari Azhar, Nasrudin dan Permainan Kotor PDIP. Antasari Azhar adalah seorang mantan Ketua Komisi Pemberantasan Korupsi yang ditangkap dan dijatuhi hukuman 18 tahun. Mantan Ketua KPK itu sudah bebas dari penjara dan hadir di acara debat kedua antara pasangan calon gubernur DKI Jakarta, 27 Januari 2017. Kicauan Antasari mendapat respons dari pengguna media sosial. Tulisan ini bertujuan untuk mendeskripsikan bentuk majas dan ragam bahasa yang digunakan dalam komentar "Wartawan Senior Bongkar Kebusukan Antasari, Nasrudin dan Permainan Jahat PDIP" (www.idnusa.com). Penelitian ini dilakukan dari bulan Januari hingga April 2017. Metode penelitian yang digunakan deskriptif kualitatif . Data dianalisis melalui teknik analisis wacana. Penelitian ini menunjukkan bahwa majas sarkasme yang digunakan dalam artikel berupa kata dan frasa. Jenis kata yang digunakan berupa kata sifat, kata benda, dan kata kerja. Sementara ragam bahasa yang digunakan antara lain berdasarkan maksudnya dan bahasa yang digunakan. Ragam bahasa berdasarkan maksudnya dapat pula dibedakan menjadi majas yang berupa harapan, umpatan, imbauan dan pernyataan. Ragam bahasa yang digunakan meliputi bahasa daerah dan bahasa asing.
\end{abstract}

Kata Kunci: majas, sarkasme, penulisan, komentar

Abstract: EdyA Effendi is a senior journalist who wrote comment about AntasariAzhar, Nasrudin and PDIP's engage in some evils. Antasari Azhar is a former head of Corruption Fight Commission who was arrested and sentenced for 18 years punishment. The ex of KPK has been free from prison in debating program of couple of candidate of Jakarta Province Governor election on January 2, 2017. Antasari's chatter got responses from social media users. Many of the written comments about AntasariAzhar are negative. This article aims at describing the form of figurative and language registers language register that used in expressing sarcasm metaphor in the comments of article "Wartawan Senior Bongkar Kebusukan Antasari, Nasrudin dan Permainan Jahat PDIP (Senior Journalist Reveals Antasari's Evil, Nasrudin And PDIP's Engage In Some Evils)" (www.idnusa.com).This study was carried out from January to April 2017. The method used is qualitative descriptive method.The data was analyzed by using discourse analysis technique.The result of the study shows that sarcasm metaphor that used in article to be data in the form of words and phrase. The type of words that used is adjectives, nouns and verbs. Besides, the language register used is based on the meaning and the language used. Language register based on meaning can be differed to be metaphor such as hoping, cursing, appealing and expressing. The language registers used are regional languages and foreign languages.

Keywords: figurative, sarcasm, writing and comments 


\section{PENDAHULUAN}

Manusia menggunakan bahasa untuk berkomunikasi dan berinteraksi satu dengan lainnya. Sebagai makhluk sosial manusia harus mampu memahami fungsi bahasa agar komunikasi yang terjalin berjalan dengan lancar. Dengan bahasa seseorang dapat mengungkapkan gagasan, ide, pikiran, dan keinginan dalam menyampaikan pendapat dan informasi. Tanpa bahasa sulit bagi manusia untuk berkomunikasi antara sesama.

Komunikasi yang dilakukan oleh manusia bisa disampaikan secara lisan dan tertulis. Komunikasi secara lisan yakni bentuk komunikasi dengan mengucapkan kata-kata secara lisan dan langsung kepada teman bicara. Biasanya komunikasi ini dapat dilakukan saat kondisi berhadapan langsung. Secara tulisan yakni komunikasi yang dilakukan melalui tulisan seperti yang dilakukan dalam kegiatan surat-menyurat melalui pos, telegram, faks, posel, dan laman internet.

Laman adalah halaman utama dari suatu situs web yang diakses oleh pengguna pada awal masuk ke situs tersebut (KBBI, 2008, hlm. 777). Ada sepuluh laman yang bisa ditemukan di internet 1) E-mail (pos-el), 2) World Wide Web (www), 3) Mailing list, 4) Ecommerce, 5) E-bangking, 6) Chatting, 7) VOIP (Voice Over Internet Protocol), 8) Telnet (Tele Networking), 9) Internet Relay Chat (IRC), dan 10) Discussion Group. Salah satu dari 10 laman yang sering dikunjungi oleh pengguna internet tersebut adalah World Wide Web (www). World Wide Web (www) merupakan layanan internet yang berupa layanan www yang sangat populer di tengahtengah masyarakat, layanan ini memungkinkan siapa saja bisa menjelajahi halaman website yang ada di internet. Para pencari informasi di internet memanfaatkan layanan $w w w$ guna mencari informasi berlimpah di internet (www. FachrysRdarizal.com).

Di era reformasi saat ini, manusia bebas berbicara dan menuliskan komentar apa saja yang diinginkan terutama di internet, baik komentar yang positif maupun yang negatif. Komentar positif bisa berupa nasihat atau saran yang bermanfaat, sedangkan komentar negatif bisa berupa umpatan, cacian dan makian. Kata-kata makian yang ditulis seringnya tidak sopan dan kasar.

Kata-kata yang kasar dan tidak sopan yang dituliskan di media (internet) ini terkadang disalahgunakan oleh pemakainya. Masyarakat tidak lagi memperhatikan kesantunan berbahasa dan cendrung menuliskan komentar yang berlebihanan. Penggunaan sarkasme yang berlebihan di media massa akan memberikan contoh yang tidak baik terhadap penggunaan bahasa yang tidak santun. Hal ini bisa menimbulkan konflik dan memancing emosi pembaca atau hanya sekadar mencari sensasi jurnalistik.

Antasari Azhar adalah seorang mantan Ketua Komisi Pemberantasan Korupsi (KPK) yang divonis hukuman penjara pada 11 Februari 2011. Ia divonis penjara 18 tahun karena terbukti bersalah turut serta melakukan pembujukan untuk membunuh Nasrudin Zulkarnaen. Pada 10 November 2016, Antasari Azhar menghirup udara bebas dengan ketentuan bebas bersyarat. Beliau menggelar jumpa pers di gedung sementara Bareskrim Polri di Kementerian KKP, Gambir, Jakarta Pusat pada 14 Februari 2017. Beliau meminta mantan Presiden Susilo Bambang Yudhoyono untuk bicara jujur. Ketika Antasari hadir di tengah-tengah pendukung Ahok-Jarot di acara debat kedua antara pasangan calon gubernur DKI Jakarta, 27 Januari 2017, banyak para pendukung yang hadir bersorak senang, dan ada juga yang berteriak-teriak kepada Antasari: Bongkar! Bongkar! 
Bongkar! Peristiwa inilah yang menimbulkan komentar-komentar positif dan negatif di media internet. Artikel tentang Antasari tersebut ditulis oleh wartawan senior Edy A. Effendi. Hal inilah yang membuat penulis tertarik untuk membahasnya dalam sebuah penelitian tentang sarkasme.

Beberapa penelitian terkait pernah dilakukan oleh (1) Maratus Solekah (2013), (2) Mega Ayu Intan Permatasari (2014), dan (3) Irfariati (2015). Maratus Solekah (2013) melakukan penelitian yang berjudul "Majas Sarkasme Pada Rubrik Kriminal dalam Koran Meteor". Dari hasil penelitian ini ditemukan bahwa bentuk majas sarkasme pada judul rubrik kriminal dalam Koran Meteor terdiri dari bentuk ejekan dan bentuk sindiran dan judul yang digunakan sebaiknya ditulis lebih sopan untuk dibaca ataupun di dengar. Mega Ayu Intan Permatasari (2014) melakukan penelitian yang berjudul "Analisis Bahasa Sarkasme Pada Rubrik Kriminal Surat Kabar Solopos Edisi September-Oktober 2013". Dari hasil penelitian tersebut ditemukan bahwa bentuk gaya bahasa sarkasme pada judul rubrik kriminal dalam surat kabar harian Solopos terdiri dari bahasa daerah, Indonesia, dan asing. Irfariati (2015) melakukan penelitian yang berjudul "Majas Sarkasme Dalam Penulisan Komentar pada Ironi Akil Mochtar, Ketua MK Yang Ditangkap KPK". Dari hasil penelitian tersebut ditemukan bahwa majas sarkasme yang digunakan berupa kata dan frasa. Penelitian ini memiliki perbedaan dengan penelitianpenelitian tersebut karena diambil dari waktu dan objek yang berbeda.

Berdasarkan latar belakang di atas, masalah penelitian ini dapat dirumuskan sebagai berikut: (1) bagaimanakah bentuk majas sarkasme yang terdapat dalam komentar pada artikel "Wartawan Senior Bongkar Kebusukan Antasari, Nasrudin dan Permainan Jahat PDIP'?
(2) ragam bahasa apa sajakah yang digunakan dalam pengungkapan majas sarkasme pada komentar di artkel "Wartawan Senior Bongkar Kebusukan Antasari, Nasrudin dan Permainan Jahat PDIP"?.

Berdasarkan permasalahan yang ada, penelitian ini bertujuan untuk: (1) mendeskripsikan bentuk majas sarkasme yang terdapat dalam komentar pada artikel "Wartawan Senior Bongkar Kebusukan Antasari, Nasrudin dan Permainan Jahat PDIP"; (2) mendeskripsikan ragam bahasa yang digunakan dalam pengungkapan majas sarkasme pada komentar di artikel "Wartawan Senior Bongkar Kebusukan Antasari, Nasrudin dan Permainan Jahat PDIP".

Menurut Keraf (2004, hlm. 112113) Majas disebut juga gaya bahasa. Gaya atau khususnya gaya bahasa dikenal dalam retorika dengan istilah style. Kata style diturunkan dari kata latin stilus, yaitu semacam alat untuk menulis pada lempengan lilin. Keahlian mengunakan alat ini akan mempengaruhi jelas tidaknya tulisan pada lempengan tadi. Kelak pada waktu penekanan dititik-beratkan pada keahlian untuk menulis indah, maka style lalu berubah menjadi kemampuan dan keahlian untuk menulis atau mempergunakan kata-kata secara indah. Gaya bahasa adalah cara mengungkapkan pikiran melalui gaya bahasa secara khas yang memperlihatkan jiwa dan kepribadian penulis. Namun, ketika disandingkan dengan kata sarkasme, artinya menjadi sangat berbeda.

Definisi sarkasme menurut Kamus Besar Bahasa Indonesia (KBBI, 2014, hlm. 1228) adalah kata-kata pedas untuk menyakiti hati orang lain, cemoohan atau ejekan kasar. Pengertian lain tentang sarkasme adalah suatu majas yang dimaksudkan untuk menyindir, atau menyinggung seseorang atau sesuatu. Sarkame dapat berupa penghinaan yang mengekspresikan rasa kesal 
dan marah dengan menggunakan katakata kasar. Majas ini dapat melukai perasaan seseorang. Dalam bahasa Indonesia, arti sarkasme berbeda dari kepercayaan banyak orang bahwa sarkasme berarti penyindiran yang menggunakan kata yang terbalik dari maksudnya, seperti ironi. (http://id.m.wikipedia.org).

Menurut Keraf (2004, hlm. 143) sarkasme merupakan suatu acuan yang lebih kasar dari ironi dan sinisme. Sarkasme adalah suatu acuan yang mengandung kepahitan dan celaan yang getir. Sarkasme dapat berupa ironi, dan juga tidak, tetapi yang jelas adalah bahwa gaya ini selalu akan menyakiti hati dan kurang enak didengar. Sarkasme dalam bahasa Indonesia dapat berupa kata, frasa, klausa dan mungkin juga kalimat. Namun, peneliti hanya membahas tentang bentuk sakasme yang berupa kata dasar dan frasa. Bentuk sarkasme yang berupa kata dasar dan frasa adalah sebagai berikut.

a. Sarkasme yang berupa kata dasar

Sarkasme yang berupa kata dasar menurut Chaer (1994, hlm. 162) merupakan satuan bahasa yang memiliki pengertian dan mempunyai satu arti. Dalam bidang semantik, kata merupakan sebuah leksem. Kata merupakan leksem yang telah mengalami proses morfologi (Kridalaksana, 1992, hlm. 12). Kata merrupakan hasil dari proses pengolahan leksem menjadi kata. Lebih lanjut menurut Kridalaksana bahwa yang berperan sebagai input dalam proses morfologi ialah leksem sebagai satuan leksikal, sedangkan kata sebagai satuan gramatikal berperan sebagai output. (Kridalaksana, 1992, hlm. 13-14).

b. Sarkasme yang berupa frasa

Sarkasme menurut Chaer (1994, hlm. 222-223) yang berupa frasa merupakan satuan gramatikal berupa gabungan kata yang bersifat nonprediktif, atau lazim juga disebut gabungan kata yang bersifat nonprediktif, atau lazim juga disebut gabungan kata yang mengisi salah satu fungsi sintaksis di dalam kalimat.

Referensi sarkasme menurut Yayat Sudaryat (dalam Irfariati, 2015, hlm. 165-166), acuan atau referen adalah sesuatu yang ditunjuk atau diacu, baik berupa benda dalam kenyataan maupun sesuatu yang dilambangkan dan dimaknai. Acuan merupakan unsur luar bahasa yang ditunjuk oleh unsur bahasa. Kata yang melambangkan pikiran dan referensi ini mengacu pada unsur atau peristiwa yang dibicarakan. Ragam bahasa berdasarkan maksudnya dapat berupa (a) umpatan, (b) imbauan, (c) perintah dn (d) ancaman. Sementara itu, jika dilihat ragam bahasa berdasarkan bahasa yang digunakan, komentar tersebut dapat dikelompokkan menjadi (a) bahasa daerah, (b) bahasa Indonesia, dan (c) bahasa asing.

\section{METODE PENELITIAN}

Metode yang digunakan dalam penelitian ini adalah deskriptif kualitatif. Metode kualitatif dilakukan dalam kondisi alamiah, langsung ke sumber data dan data yang dihasilkan bersifat deskriptif (Sugiyono, 2009: 13). Penelitian ini dilakukan dari Januari 2017 hingga April 2017, di Balai Bahasa Riau. Data dalam penelitian ini diperoleh dengan teknik membaca, kemudian mencatat hal-hal yang dianggap perlu dengan langkah sebagai berikut.

1. Mengunduh dari komentar artikel "Wartawan Senior Bongkar Kebusukan Antasari, Nasrudin dan Permainan Jahat PDIP" (www.idnusa.com).

2. Mencatat semua komentar yang dianggap sesuai dan masuk kategori majas sarkasme.

3. Mengelompokkan majas sarkasme berdasarkan kerangka teori. 


\section{PEMBAHASAN}

Edy A adalah wartawan senior. Dia pernah menduduki jabatan penjaga gawang budaya di harian Media Indonesia. Selain menulis di media massa, ia juga menulis banyak buku dan juga sebagai editorial. Ia menulis tentang Antasari, Nasrudin dan permainan kotor PDIP. Berita yang ditulis oleh Edy tersebut menuai banyak komentar di media sosial.

Dari hasil pengumpulan data, bentuk sarkasme yang terdapat dalam wacana komentar "Wartawan Senior Bongkar Kebusukan Antasari, Nasrudin dan Permainan Jahat PDIP" adalah sebagai berikut.

\section{Tataran}

Dilihat dari tatarannya, diksi atau pilihan kata yang digunakan dalam penulisan komentar-komentar pada "Wartawan Senior Bongkar Kebusukan Antasari, Nasrudin dan Permainan Jahat PDIP" diklasifikasikan sebagai berikut

\section{a. Kata}

Pilihan kata atau diksi yang digunakan sebagai umpatan yang kasar berupa kata sifat, kata benda, dan kata kerja.

Tabel 1 Diksi Umpatan Kasar yang Berupa Kata Sifat

\begin{tabular}{|c|c|c|}
\hline No & Kata sifat & Kalimat \\
\hline 1 & sadis & $\begin{array}{l}\text { (1) Ingat pak antasari... ketika bapak menunjuk pak SBY } \\
\text { ketika itu juga } 3 \text { jari bpk yg mengarah ke diri bapak.. jadi } \\
\text { beristigfarlah pak dekatkan diri dengan allh swt.. syukuri } \\
\text { nikmatNYA hati" dengan rezim yang berkuasa skarang pak } \\
\text { sangat sadis... (Oby Hasan Keliora, Koordinator DIV } \\
\text { ADVOKASI di Lbhl 8:33 } 15 \text { Februari 2017) }\end{array}$ \\
\hline 2 & selingkuh & $\begin{array}{l}\text { (2)Makanya gara-gara gatal selangkanganmu itulah jd hancur } \\
\text { karirmu, istri ada tapi msh slingkuh sama caddy. (Syuqri } \\
\text { Tanzoenk, Bekerja di Barcelona FC } 21: 2115 \text { Feberuari 2017) }\end{array}$ \\
\hline 3 & takut & $\begin{array}{l}\text { (3) Biar dibuktikan olh org2 yg masih punya hati nurani tuk } \\
\text { bicara jujur.. takut pd Allah jgn pd manusia. (Munipah Ip, IKIP } \\
\text { Jakarta 15:30 15 Februari 2017) }\end{array}$ \\
\hline 4 & dendam & $\begin{array}{l}\text { (4)Se7....lbh baik beristigfar drpd membalas dendam...sbgm } \\
\text { bapak berstatement saat keluar dari penjara ....bhw bapak sdh } \\
\text { menguburkan semua masalah dan tidak ada dendam kpd } \\
\text { siapapun, ingat itu pak Antasari. (Ibrahim Tokan, Universitas } \\
\text { Hasanuddin 04:35 16 Februari 2017) }\end{array}$ \\
\hline 5 & mual & $\begin{array}{l}\text { (5) Liat muke nye aje mual..., yakin lah kebenaran akan } \\
\text { terkuak dg sendir nya (Tia Cinta, Purchasing Dept di Angka } \\
\text { Teknik Sepadan PT, 2:29 } 15 \text { Februari 2017) }\end{array}$ \\
\hline 6 & tua & $\begin{array}{l}\text { (6) Udah tua juga bos, mending banyakin istiqfar minta ampun } \\
\text { pada Allh jangan sama manusia..... (Seger Mardjadi, } \\
\text { Universitas Indonesia, } 15 \text { Februari } 2017 \quad 18: 00)\end{array}$ \\
\hline 7 & cabul & $\begin{array}{l}\text { (7) Kasus cabul lalu pembunuhan sekarang ngoceh mulutnya } \\
\text { bau........ (Iman Tauhid Owner di TRD Clothing ITC } \\
\text { Cempaka Mas 15:42 15 Februari 2017) }\end{array}$ \\
\hline 8 & busuk & $\begin{array}{l}\text { (8) Sdh pasti manuver busuk dan jahat...... } \\
\text { Istighfar...... (Rogin Syafany, } 15 \text { Februari 2016, 6:03) }\end{array}$ \\
\hline 9 & gatal & $\begin{array}{l}\text { (9)Makanya gara-gara gatal selangkanganmu itulah jd hancur } \\
\text { karirmu, istri ada tapi msh slingkuh sama caddy. (Syuqri } \\
\text { Tanzoenk, Bekerja di Barcelona FC } 21: 2115 \text { Feberuari 2017) }\end{array}$ \\
\hline 10 & kasihan & $\begin{array}{l}\text { (10) Kasihan!!! (Citra Alvivaldino UNAKI, 23:59 Februari } \\
\text { 2017) }\end{array}$ \\
\hline
\end{tabular}




\begin{tabular}{|l|l|l|}
\hline 11 & kapok & $\begin{array}{l}\text { (11) Udag apa pa,,. Ya klau dag keluar udah apa jiem, ga } \\
\text { kapok apa di sel...taubat dag pd tuwir, mau dikata apa ama } \\
\text { cucu. (Desi Yanti, Universitas Terbuka 2:24 15 Februari 2017) }\end{array}$ \\
\hline
\end{tabular}

Pilihan kata-kata seperti sadis, dilakukannya. Kicauan Antasari di selingkuh, takut, dendam, mual, tua, media terutama di media sosial membuat cabul, busuk, gatal, kasihan, dan kapok mantan Presiden Susilo Bambang merupakan umpatan yang ditujukan Yudhoyono melakukan klarikasi atas langsung untuk Antasari Azhar atas berita yang beredar di masyarakat tindakan dan perbuatan yang telah

Tabel 2 Diksi Umpatan Kasar yang Berupa Kata Benda

\begin{tabular}{|l|l|l|}
\hline No & \multicolumn{1}{|c|}{ Kata benda } & \multicolumn{1}{|c|}{ Kalimat } \\
\hline 1 & kejahatan & $\begin{array}{l}\text { (12) Gak ada gunanya semua bukti" kejahatan atau kebusukan } \\
\text { "selagi mereka" masih berkuasa. Jalan satu"nya adalah } \\
\text { REVOLUSI (Rita Martiningsih, Lembang Jawa Barat, 00:04 } \\
\text { 15 Februari 2017) }\end{array}$ \\
\hline 2 & setan & $\begin{array}{l}\text { (13) Ternyata manusia ini setan juga.... } \\
\text { Wajar dihabisi d zaman SBY } \\
\text { (Admis Hartono (Bekerja di Red Sea Marine Services) 2:05 } \\
\text { Februari 2017) }\end{array}$ \\
\hline 3 & selangkangan & $\begin{array}{l}\text { (14)Makanya gara-gara gatal selangkanganmu itulah jd } \\
\text { hancur karirmu, istri ada tapi msh slingkuh sama caddy. } \\
\text { (Syuqri Tanzoenk, Bekerja di Barcelona FC 21:21 15 } \\
\text { Feberuari 2017) }\end{array}$ \\
\hline 4 & pecundang & $\begin{array}{l}\text { (15) Pecundang dan sudah bau tanah dibebaskan supaya } \\
\text { insyap malah seperti anjing. (Kuswanto Herdiansyah } \\
\text { Umarbakry di PNS Pemda DKI 4:51 Februari 2017) }\end{array}$ \\
\hline 5 & laknat & $\begin{array}{l}\text { (16)Si kumis bukannya tobat........malahan kena laknat } \\
\text { (Darsono Susanto, 6:03 15 Februari 2017) }\end{array}$ \\
\hline 6 & binatang & $\begin{array}{l}\text { (17)Oroknya binatang .......(Meipril Syahmi di kontraktor } \\
\text { dan konsultan 10:01 15 Februari 2017) }\end{array}$ \\
\hline 7 & anjing & $\begin{array}{l}\text { (18)Pecundang dan sudah bau tanah dibebaskan supaya insyap } \\
\text { malah seperti anjing. (Kuswanto Herdiansyah Umarbakry di } \\
\text { PNS Pemda DKI 4:51 Februari 2017) }\end{array}$ \\
\hline 8 & terdakwa & $\begin{array}{l}\text { (19) Apa devinisi grasi..berarti ampunan yg diberikan presiden } \\
\text { kepada terdakwa setelah hakim memutus perkara, apaka ini } \\
\text { artinya pengakuan sana dengan menyatakan saya bersalah? }\end{array}$ \\
\hline 9 & kebusukan & $\begin{array}{l}\text { (20) Gak ada gunanya semua bukti" kejahatan atau } \\
\text { kebusukan" selagi mereka" masih berkuasa. Jalan satu"nya } \\
\text { adalah REVOLUSI (Rita Martiningsih, Lembang Jawa Barat, } \\
\text { 00:04 15 Februari 2017) }\end{array}$ \\
\hline
\end{tabular}

Pilihan kata-kata seperti kejahatan, setan, selangkangan, pecundang, laknat, binatang, anjing, terdakwa dan kebusukan merupakan umpatan yang ditujukan langsung untuk Antasari Azhar atas tindakan dan perbuatan yang telah dilakukannya.

Tabel 3 Diksi Umpatan Kasar yang Berupa Kata Kerja

\begin{tabular}{|l|l|l|l|}
\hline No & \multicolumn{1}{|c|}{ Kata Kerja } & \multicolumn{3}{|c|}{ Kalimat } \\
\hline 1 & dompleng & $\begin{array}{l}\text { (21) Pak antasari, kl bisa mah lebih baik nggak usah di ungkit } \\
\text { lagi. Soalnya pasti muter terus. Khawatirnya ada yang }\end{array}$ \\
\hline
\end{tabular}




\begin{tabular}{|c|c|c|}
\hline & & $\begin{array}{l}\text { dompleng kepentingan, akhirnya bpk juga yang kena. Kata } \\
\text { orang minang, seperti mengukur kain sarung. Nggak ada } \\
\text { endingnya (Fahdilla Mardanis Lembang Jawa Barat, 2:53 } 15 \\
\text { Februari 2017) }\end{array}$ \\
\hline 2 & nuduh & $\begin{array}{l}\text { (22) Iya mkny uda pa..ngapain bpk } n u d u h \text { pa SBY klo nanti g } \\
\text { terbukti yg nanggung siapa kita sndr...yg lain pasti pada kabur.. } \\
\text { (Yani Suryani, Bekerja di Usaha } 0: 2415 \text { Februari 2017) }\end{array}$ \\
\hline 3 & diperalat & $\begin{array}{l}\text { (23)Diperalat doank pak.. ntr kl sudh ada hasilnya jg ditendang } \\
\text { sm merekam. (Heralinda Leni, bekerja di Pt Paramount bed, } 15 \\
\text { Februari } 2017 \text { 4:39) }\end{array}$ \\
\hline 4 & terjebak & $\begin{array}{l}\text { (24) Hati-hati pak antasari, nikmati ajalah kebebasan jgn } \\
\text { terjebak lagi atas kepentingan kelompok tertentu utk } \\
\text { memanfaatkan bapak sebagai alat. (Sukirman Ben2, United } \\
\text { press International, 2:45 February 2017) }\end{array}$ \\
\hline 5 & mampus & $\begin{array}{l}\text { (25)Hayooo pa SBY hajar balik antasari masukkan kembali ke } \\
\text { penjara biar sampai mampus di dalam sel di kupret itu. Rudy } \\
\text { Rudy (CEO di Wiraswasta), 5:11 } \\
\text { 15 Februari 2017) }\end{array}$ \\
\hline 6 & bongkar & $\begin{array}{l}\text { (26)Ohhh ternyata } \\
\text { Catatan Abdullah hehamahua Bongkar Siapa Sebenarnya } \\
\text { Antasari } \\
\text { (Ndei Ndie, 18:36 } 15 \text { Februari 2017) } \\
\text { (27) Bongkaaaaaarrrrrrr..... } \\
\text { (Gareng Rdb, UII 15 Februari 2017) } \\
\text { (28) Semakin seru ayo bongkar terus } \\
\text { (Gangsar Agus Setyawan, Kepemilikan CV Mtec professional } \\
\text { 15 Februari 2017) }\end{array}$ \\
\hline 7 & dilempar & $\begin{array}{lclll}\text { (29)Yang main bola tuan kok dilempar } & \text { ke } \\
\text { SBY......(Muhammad Azman Piliang) } & & \\
\end{array}$ \\
\hline 8 & dijegal & $\begin{array}{l}\text { (30)Msh ingat pak anies .....jadi timses....krn org } \\
\text { sipil....dijegal deh....padahal peranx besar memenangkan } \\
\text { presiden sekarang (Eni Rusmawardani, 19:33 } 15 \text { Februari 2017) }\end{array}$ \\
\hline 9 & kabur & $\begin{array}{l}\text { (31)Iya mkny uda pa..ngapain bpk nuduh pa SBY klo nanti g } \\
\text { terbukti yg nanggung siapa kita sndr...yg lain pasti pada kabur.. } \\
\text { (Yani Suryani, Bekerja di Usaha } 0: 24 \text { 15 Februari 2017) }\end{array}$ \\
\hline 10 & dihabisi & $\begin{array}{l}\text { (32)Ternyata manusia ini setan juga.... } \\
\text { Wajar dihabisi d zaman SBY } \\
\text { (Admis Hartono (Bekerja di Red Sea Marine Services) 2:05 } \\
\text { Februari 2017) }\end{array}$ \\
\hline 11 & ditendang & $\begin{array}{l}\text { (33) } D i \text { peralat doank pak.. ntr } \mathrm{kl} \text { sudh ada hasilnya jg } \\
\text { ditendang sm merekam. (Heralinda Leni, bekerja di } \mathrm{Pt} \\
\text { Paramount bed, } 15 \text { Februari } 2017 \text { 4:39) }\end{array}$ \\
\hline
\end{tabular}

\section{b. Frasa}

Dilihat dari tatarannya, diksi atau pilihan kata yang digunakan dalam penulisan komentar-komentar pada "Wartawan Senior Bongkar Kebusukan Antasari, Nasrudin dan Permainan Jahat
PDIP” diklasifikasikan berdasarkan frasa.

Pilihan kata atau diksi yang digunakan sebagai umpatan yang kasar berupa frasa dapat dilihat pada tabel 4 berikut. 
Tabel 4 Umpatan Kasar berupa Frasa

\begin{tabular}{|c|c|c|}
\hline No & Frasa & Kalimat \\
\hline 1 & $\begin{array}{l}\text { seperti mengukur kain } \\
\text { sarung }\end{array}$ & $\begin{array}{l}\text { (34) Pak antasari, kl tro mah lebih baik nggak usah di } \\
\text { ungkit lagi. Soalnya pasti muter terus. Khawatirnya ada } \\
\text { yang dompleng kepentingan, akhirnya bpk juga yang kena. } \\
\text { Kata orang minang, seperti mengukur kain sarung. Nggak } \\
\text { ada endingnya (Fahdilla Mardanis Lembang Jawa Barat, } \\
\text { 2:53 15 Februari 2017) }\end{array}$ \\
\hline 2 & diam adalah waktu & $\begin{array}{l}\text { (35) Bpk ASA diam adalah waktu yang paling tepat buat } \\
\text { bpk lupakan barter grasi dgn si nganu.....(Abbas Anshari, } \\
\text { SPP-SPMA } 2: 25 \quad 15 \text { Februari 2017) }\end{array}$ \\
\hline 3 & $\begin{array}{l}\text { kebenaran akan terkuak } \\
\text { dengan sendirinya }\end{array}$ & $\begin{array}{l}\text { (36)Liat muke nye aje mual..., yakin lah } \\
\text { kebenaran akan terkuak dg sendir nya (Tia Cinta, } \\
\text { Purchasing Dept di Angka Teknik Sepadan PT, 2:29 } 15 \\
\text { Februari 2017) }\end{array}$ \\
\hline 4 & $\begin{array}{l}\text { semakin banyak menebar } \\
\text { troke permusuhan pasti } \\
\text { akan menuai badai yang } \\
\text { tak akan henti }\end{array}$ & $\begin{array}{l}\text { (37)Sudahlah Antasari kamu sudah tua dan sekarang sudah } \\
\text { keluar dari penjara dinikmati dan disyukuri saja......Di } \\
\text { contoh aja itu pak Susno Duaji........Hidupnya sekarang } \\
\text { tenang.......Pak Antasari mau cari apalagi? Ingat...... } \\
\text { semakin banyak menebar troke permusuhan pasti akan } \\
\text { menuai badai yg tak akan henti..... lebih baik di sisa sisa } \\
\text { umurnya ini banyak bersabar dan bersyukur saja. (Sugeng } \\
\text { Hindarjo Universitas Diponegoro, , 21:51 } 15 \text { Februari } \\
\text { 2017) }\end{array}$ \\
\hline 5 & bau tanah & $\begin{array}{l}\text { (38)Pecundang dan sudah bau tanah dibebaskan supaya } \\
\text { insyap malah seperti anjing. (Kuswanto Herdiansyah } \\
\text { Umarbakry di PNS Pemda DKI 4:51 Februari 2017) }\end{array}$ \\
\hline 6 & ngoceh mulutnya bau & $\begin{array}{l}\text { (39)Kasus cabul lalu pembunuhan sekarang ngoceh } \\
\text { mulutnya bau........ (Iman Tauhid Owner di TRD } \\
\text { Clothing ITC Cempaka Mas 15:42 } 15 \text { Februari 2017) }\end{array}$ \\
\hline 7 & $\begin{array}{l}\text { bukannya tobat malah } \\
\text { cari masalah }\end{array}$ & $\begin{array}{l}\text { (40)Bukannya tobat malah cari masalah } \\
\text { Bentar lagi AA dikasih jabatan. (Then's Ibrahim Adham } \\
\text { Bekerja di Black ID Indonesian Apparel 7:45 } 15 \text { Februari } \\
\text { 2017) }\end{array}$ \\
\hline 8 & $\begin{array}{l}\text { kemaren bui, besok } \\
\text { strooke }\end{array}$ & $\begin{array}{l}\text { (41) Kmrn bui, besok troke } \\
\text { (Metarief, 2:00 15 Februari 2017) }\end{array}$ \\
\hline 9 & hidung belang & $\begin{array}{l}\text { (42)Hidung belang jangan dipercaya. (Kabaluddin Ucok, } \\
\text { 16:07 } 15 \text { Februari 2017) }\end{array}$ \\
\hline 10 & liang kubur dah dekat & $\begin{array}{l}\text { (43) Pak, istighfar, liang kubur dah dekat. (Metarief, 1:59 } \\
\text { Februari 2017) }\end{array}$ \\
\hline 11 & masuk penjara & $\begin{array}{l}\text { (44) Sudh sudh pak........jangan sampai } 2 \text { x masuk } \\
\text { penjara (Tisna, Simpang III 1:19 17 Februari 2017) }\end{array}$ \\
\hline 12 & ternyata ular juga & $\begin{array}{l}\text { (45) Ternyata ular juga.....(Ade Iman, Politeknik UI 4:03 } \\
15 \text { Februari 2017) }\end{array}$ \\
\hline 13 & udaaaaaah tua ngemis2 & $\begin{array}{l}\text { (46) Udaaaaaah tua ngemis2 } \\
\text { (Bambang Saputra, 2:01 } 15 \text { Februari 2017) }\end{array}$ \\
\hline 14 & Udaaaaah tidur aja & $\begin{array}{l}\text { (47) Antasariiiii antasari.... Udaaaaah tidur ajaaaa } \\
\text { Keakehan jail..............(Bambang Saputra } 1: 52 \quad 15 \\
\text { Februari 2017) }\end{array}$ \\
\hline 15 & $\begin{array}{l}\text { ada utang yang harus } \\
\text { dibayar }\end{array}$ & $\begin{array}{l}\text { (48) Antasari Dikasih grasi dr jokowi bukan gratis...ada } \\
\text { utang yg hrs dibayar dn lagi artinya mengakui salah } \\
\text { setelah permohonan PK ke MA ditolak...wee (Nur } \\
\text { Aisyah, UNSRI, 06:21 } 15 \text { Februari 2017) }\end{array}$ \\
\hline
\end{tabular}




\begin{tabular}{|l|l|l|}
\hline 16 & $\begin{array}{l}\text { Yang berkhianat menjadi } \\
\text { anak asing }\end{array}$ & $\begin{array}{l}\text { (49) Musuh terberat bukan... } \\
\text { Melawan bangsa lain... } \\
\text { Tapi melawan saudara sebangsamu... } \\
\text { Yang berkhianat menjadi anak asing (Drs.M Hatta) } \\
\text { (Asep Dahinn, bekerja di Permata Bank 15 Februari 2107) }\end{array}$ \\
\hline 17 & siap-siap masuk lagi & $\begin{array}{l}\text { (50)Mendung kalau benar tuduhannyakalau nggak bener } \\
\text { siap2 msk lagi...tapi tenang msh ada grasi ke 2 he.....he } \\
\text { (Su Wirman, IAIN Raden Patah Palembang, 19:17 15 } \\
\text { Februari 2017) }\end{array}$ \\
\hline 18 & seharusnya tobat & $\begin{array}{l}\text { (51) Seharusnya tobat (Zohrianto Anto, MTs Darul } \\
\text { Furqon, 2:58 15 Februari 2017) }\end{array}$ \\
\hline 19 & $\begin{array}{l}\text { kayak preman pasar } \\
\text { glodok }\end{array}$ & $\begin{array}{l}\text { (52) Pak antaguna coba cukur tuuh kumisnya ......biar } \\
\text { ganteng ..... kalau kumisan kayak preman pasar glodok. } \\
\text { (Bambang Saputra, 1:58 16 Februari 2017) }\end{array}$ \\
\hline 20 & orang busuk dok & $\begin{array}{l}\text { (53) Orang busuk dok (Teddy Arrofi, Universitas Krisna } \\
\text { Dwiparyana, 7:55 15 Februari 2017) } \\
\text { (54) Wow hahha hah masa } \\
\text { (Unan Marpaung, Universitas Langkangbuana, 4:35 15 } \\
\text { Februari 2017) }\end{array}$ \\
\hline 21 & Wow hahha hah masa & $\begin{array}{l}\text { (55) Kasian....sdhlah..... } \\
\text { (Ibbha GaseloFc, Jomblo 100\% di PT Mecari Cinta Sejati, } \\
\text { 2:34 15 Februari 2017 }\end{array}$ \\
\hline 22 & Kasian....sdlah..... &
\end{tabular}

\section{Ragam Bahasa}

Dilihat dari ragam bahasanya, majas sarkasme yang digunakan dalam penulisan komentar-komentar pada "Wartawan Senior Bongkar Kebusukan Antasari, Nasrudin dan Permainan Jahat PDIP” dapat dilihat berdasarkan maksudnya dan berdasarkan bahasa yang digunakan.

\section{a. Dilihat dari segi maksudnya}

Berdasarkan maksudnya, kalimat yang mengandung majas sarkasme terdiri dari umpatan, harapan, imbauan, dan pernyataan.

Tabel 5 Majas Sarkasme dari Segi Maksud

\begin{tabular}{|c|c|c|}
\hline No & Maksud & Kalimat \\
\hline 1 & umpatan & $\begin{array}{l}\text { (56)Siapa yang menabur angin, akan menuai badai (Lilik } \\
\text { Kurniawah, STM Negeri Purworejo 1:19 Februari 2017) } \\
\text { (57)Pengin exis lagi udah nggak laku boss... } \\
\text { (Joko Hari, PNS di Mojokerto 19:45 } 15 \text { Februari 2017) } \\
\text { (58)Panggung sandiwara di negeri ini makin } \\
\text { rame................. } \\
\text { (Mujihani Nur, 0::31 } 15 \text { Februari 2017) }\end{array}$ \\
\hline 2 & harapan & $\begin{array}{l}\text { (59)Tau ini tau itu.. akhir cerita nol juga } \\
\text { hasilnya.... Rakyat Indonesia butuh kenyataan..bukan } \\
\text { impian yang ditawarkan... (Iwan manik } 16 \text { feb } 2017 \\
\text { 11.18) } \\
\text { (60)Moga Indonesia bisa ada pemimpin yg bisa membawa } \\
\text { masyarakatnya hidup rukun dan damai dan sling } \\
\text { menghargai sesama umat beragama .amin (Cakno, } \\
\text { Kabupaten Sorong } 0: 25 \text { 15 Februari 2017) }\end{array}$ \\
\hline 3 & imbauan & $\begin{array}{l}\text { (61) Tau ini tau itu.. akhir cerita nol juga hasilnya.... } \\
\text { Rakyat Indonesia butuh kenyataan..bukan impian yang } \\
\text { ditawarkan... } \\
\text { (Iwan Manik, Kepemilikan di Self-Employed 20:1815 }\end{array}$ \\
\hline
\end{tabular}




\begin{tabular}{|l|l|l|}
\hline & & $\begin{array}{l}\text { Februari 2017) } \\
\text { (62) Pak antasari, drpd ngomong ini-itu mendingan } \\
\text { banyakin ibadah sambil momong cucu......... } \\
\text { (Faishal Abdul Halim (UII) 15 Februari 2017) }\end{array}$ \\
\hline 4 & pernyataan & (63) Kumis ingat umur \\
& & (Gunawan Wiby S, Operator di PT Jaya GLASINDO \\
& ABADI) 18:42 15 Februari 2017) \\
\hline
\end{tabular}

\section{b. Dilihat dari Bahasa yang Digunakan}

Berdasarkan bahasa yang digunakan, majas sarkasme yang dipakai dalam komentar ini menggunakan bahasa

daerah dan bahasa asing. Bahasa daerah dan bahasa asing yang digunakan tidak benar-benar utuh karena dicampur oleh bahasa Indonesia.

Tabel 6 Bahasa Daerah

\begin{tabular}{|l|l|l|}
\hline No & \multicolumn{1}{|c|}{ Kata/frasa } & \multicolumn{1}{|c|}{ Kalimat } \\
\hline 1 & kupret & $\begin{array}{l}\text { (64) Hayooo pa SBY hajar balik antasari masukkan kembali ke } \\
\text { penjara biar sampai mampus di dalam sel di kupret itu. (Rudy } \\
\text { Rudy CEO di Wiraswasta, 5:11 15 Februari 2017) }\end{array}$ \\
\hline 2 & gregetan & $\begin{array}{l}\text { (65) Kl partai 1 itu emg mrasa lg brkuasa, untk saat ini hukum } \\
\text { mrasa mrk yg paya, bkin gregetan bnr. (Puspita Kota Surakarta } \\
\text { 15 Februari 2017 9:41) }\end{array}$ \\
\hline 3 & keakehan & $\begin{array}{l}\text { (66) Antasariiiii antasari... Udaaaaah tidur ajaaaa } \\
\text { Keakehan jail...............(Bambang Saputra 1:52 15 Februari } \\
\text { 2017) }\end{array}$ \\
\hline
\end{tabular}

Tabel 7 Bahasa Asing

\begin{tabular}{|l|l|l|}
\hline No & \multicolumn{1}{|c|}{ Kata } & \multicolumn{1}{|c|}{ Kalimat } \\
\hline 1 & ending & $\begin{array}{l}\text { (67) Pak antasari, kl bisa mah lebih baik nggak usah di ungkit } \\
\text { lagi. Soalnya pasti muter terus. Khawatirnya ada yang } \\
\text { dompleng kepentingan, akhirnya bpk juga yang kena. Kata } \\
\text { orang minang, seperti mengukur kain sarung. Nggak ada } \\
\text { endingnya (Fahdilla Mardanis Lembang Jawa Barat, 2:53 15 } \\
\text { Februari 2017) }\end{array}$ \\
\hline 2 & statement & $\begin{array}{l}\text { (68) Se7...lbh baik beristigfar drpd membalas dendam...sbgm } \\
\text { bapak berstatement saat keluar dari penjara ....bhw bapak sdh } \\
\text { menguburkan semua masalah dan tidak ada dendam kpd } \\
\text { siapapun, ingat itu pak Antasari. (Ibrahim Tokan, Universitas } \\
\text { Hasanuddin 04:35 16 Februari 2017) }\end{array}$ \\
\hline 3 & unfaitful & $\begin{array}{l}\text { (69)Udah lah Pak gak usah unfaithful mengung (Aiman Khan, } \\
\text { 12:18 Februari 2017) }\end{array}$ \\
\hline 4 & exist & $\begin{array}{l}\text { (70)Pengin exis lagi udah nggak laku boss... } \\
\text { (Joko Hari, PNS di pemerintah kab.Mojokerto 19:45 15 } \\
\text { Februari 2017 }\end{array}$ \\
\hline 5 & istiqomah & $\begin{array}{l}\text { (71) Istiqomah.......... lah (Ratuneneng Hasanah, Bekerja di } \\
\text { Wiraswasta 3:23 15 Februari 2017) }\end{array}$ \\
\hline
\end{tabular}

\section{PENUTUP}

Berdasarkan hasil penelitian dan analisis data yang telah dilakukan, dapat disimpulkan bahwa majas sarkasme yang terdapat di wacana grup komentar www.idnusa.com) "Wartawan Senior Bongkar Kebusukan Antasari, Nasrudin dan Permainan Jahat PDIP", berupa kata dan frasa. Jenis-jenis kata yang 
digunakan berupa kata sifat, kata benda dan kata kerja. Ragam bahasa yang digunakan antara lain berdasarkan maksudnya dan bahasa yang digunakan. Ragam bahasa berdasarkan maksudnya dapat pula dibedakan menjadi majas yang berupa umpatan, harapan, imbauan dan pernyataan. Sedangkan ragam bahasa yang digunakan yaitu bahasa daerah dan bahasa asing. Bahasa daerah dan bahadsa asing yang digunakan dalam komentar ini tidak secara utuh karena dicampur dengan bahasa Indonesia.

\section{DAFTAR PUSTAKA}

Chaer, A. (1994). Pengantar Semantik Bahasa Indonesia. Jakarta: Rineka Cipta.

Irfariati. (2015). Majas Sarkasme Dalam Penulisan Komentar Pada "5 Ironi Akil Mochtar. Ketua MK Yang Ditangkap KPK." Jurnal Madah Balai bahasa Provinsi Riau.

Keraf, G. (2004). Diksi dan Gaya Bahasa. Jakarta: Gramedia Pustaka.

Kridalaksana, H. (1992). Pembentukan Kata dalam Bahasa Indonesia. Jakarta: PT Gramedia Pustaka Utama.

Mega Ayu Intan Permata Sari. (2014). Analisis Bahasa Sarkasme Pada Rubrik Kriminal Surat Kabar Solopos Edisi September-Oktober. Skripsi. Universitas Muhammadyah, Surakarta.

Rizal, Fachrys. 10 Macam-macam Layanan Internet. www.fachrysRizal.com>2013.07 diunduh 5 April 2017.

Solekah, M. (2013). Majas Sarkasme Pada Rubrik Kriminal Dalam Koran Meteor. Skripsi. Universitas Muhammadyah, Surakarta. eprints.ums.ac.id diunduh 8 Februari 2017
Sugiyono (2009) Metode Penelitian Kuantitatif, Kualitatif dan $R \& D$. Bandung: Alfabeta.

Sugono, D., dkk. (2008). Kamus Besar bahasa Indonesia. Cetakan ketujuh, Edisi Keempat. Jakarta: PT Gramedia Pustaka Utama. http://id.m.wikipedia.org >wiki >Sarkasm e diunduh 4 April 2017 